Agro-Science Journal of Tropical Agriculture, Food, Environment and Extension Volume 10 Number 2 May 2011 pp. $1-6$

ISSN 1119-7455

\title{
THE EFFECTS OF FOUR RATIOS OF ORGANIC TO INORGANIC MANURES ON SOIL PHYSICOCHEMICAL PROPERTIES AND MAIZE YIELD.
}

\author{
Asadu C.L.A. and Nwajiaku I.M \\ Department of Soil Science, University of Nigeria, Nsukka, Nigeria
}

\begin{abstract}
This work was carried out to assess the potential effects of combined use of organic and inorganic fertilizers on the physicochemical properties of an ultisol and maize yield. The experiment was carried out first in the greenhouse and then evaluated in the field. In the greenhouse seven treatments namely 0.4t/ha N.P.K, 10t/ha pig dung, 0.2t/ha N.P.K +5t/ha pig dung, 0.25t/ha N.P.K + 2.5t/ha pig dung, $0.30 t / h a$ N.P.K +1.25t/ha pig dung, $0.35 t / h a$ N.P.K $+0.65 t / h$ a pig dung, control were evaluated using a Completely Randomized Design (CRD) replicated four times. The inorganic fertilizer used was NPK 15:15:15 while the organic manure was pig dung. The results indicated significant differences $(P \leq 0.05)$ in plant height, leaf area and dry matter as well as in most of the soil physicochemical properties $(P \leq$ 0.05). At the end of the greenhouse experiment, the best combined ratios of organic and inorganic fertilizers with the uncombined ones were used for field evaluation.there for the field evaluation these five treatments namely, N.P.K at 0.4t/ha, pig dung at 10t/ha, 0.25 t/ha N.P.K + 2.5t/ha pig dung, 0.30 t/ha N.P.K $+1.25 t / h a$ pig dung and control were involved using a Randomized Complete Block Design $(R C B D)$ replicated three times. The results also indicated significant differences $(P \leq 0.05)$ in the plant height, leaf area, dry matter, maize cob, grain yield and weight of the chaff with pig dung only (10t/ha) being the most superior in all the agronomic properties evaluated followed by one of the combined ratios of organic and inorganic fertilizer $(0.25 t / h a$ N.P.K $+2.5 t / h$ a pig dung). From the study the use of only organic manure showed outstanding effects, but 0.25 t/ha N.P.K +2.5 t/ha pig dung combination was a comparable alternative.
\end{abstract}

Keyword: Organic manure , compound fertilizer (NPK), soil physicochemical properties, maize yield.

\section{INTRODUCTION}

The use of both organic and inorganic fertilizers by farmers' world wide aims to increase and sustain agricultural productivity of soils. The positive effects from these materials are known to be the enhanced nutrient inputs to soils resulting to improved soil physical and chemical properties. The effects of separate or individual and combined applications of organic and inorganic materials on soils and crops are complex. However, it appears for certain that the quality and quantity attributes are the driving forces towards basic processes in soil such as nutrient mineralization and release and the overall effectiveness of added material on crop yield.

Maize production has become very popular and the crop is widely grown in many countries of the world. In recent times production of hybrid maize has been given wide publicity among maize farmers in Nigeria. The use of organic manure and particularly $\mathrm{NPK}, \mathrm{Mg}$ and farmyard manure has been shown to result to high yield of crop (Uzo and Asiegbu , 1982). Stewart et al (1966) reviewed the effects of long term application of mineral fertilizers on the productivity of ultisols. They indicated that different rates of $\mathrm{N}$, and $\mathrm{P}$ fertilizers applied for ten years of corn production greatly decreased $\mathrm{pH}$, slightly increased soil $\mathrm{N}$ and largely increased soil $\mathrm{P}$ but only raised productivity when the application was high. Olayinka et al. (1985) observed that plant concentration of $\mathrm{N}, \mathrm{P}$, and $\mathrm{Ca}$ increased as a result of application of amended sawdust which led to an increase in dry matter yield of maize (Zea mays) while there was a decrease in yield in the greenhouse experiment.

Jacinthe et al. (2002) evaluated the potential of crop residue (wheat straw) addition to $\mathrm{Mg}$ and nitrogen fertilizers. The yield from the treatment with the mixture out-weighed that from the single treatment. This supports strongly the combination of the both organic manure and inorganic materials as they aid crop and improve soil physical and chemical properties. In addition to improving soil, they have been found to improve soil reactions and thereby serve as alternative to lime. The present study evaluated the effects of combined organic and inorganic fertilizers in four ratios on soil physicochemical properties and the performance of maize. 


\section{MATERIAL AND METHODS}

Two experiments were conducted under two environments; greenhouse and field. The field experiment was conducted under rain-fed conditions at University of Nigeria Nsukka, (UNN) southeastern Nigeria (Latitude $06^{0} 51^{0} \mathrm{~N}$, Longitude $07^{\circ} 24$ ' $\mathrm{E}$ and altitude of about $447 \mathrm{~m}$ ) between April and July. The rainfall pattern is bimodal. The mean annual minimum rainfall is $1200 \mathrm{~mm}$ while the mean annual maximum rainfall is $2000 \mathrm{~mm}$ spread between April to early November. There is a short spell in August popularly referred to as "August break". At the onset of rain, it is violent and often torrential lasting for 1-2 hours. The soil was a well-drained ferallitic sandy loam classified as an ultisol.

\section{Greenhouse Trial}

The soils used in greenhouse trial were collected from the Department of Soil Science Research Farm beside the Faculty of Agriculture, UNN Metrological Station at the depth of 0-20 cm. The soil samples collected were air-dried under a room temperature of about $30^{\circ} \mathrm{C}$, crushed and passed through a 2-mm sieve. The samples were analyzed to determine the various physical and chemical properties of the soil. The animal manure (pig dung) which was collected from the Faculty of Agriculture Farm, UNN was also analyzed. A total of 28 pots each containing $2 \mathrm{~kg}$ of this soil were used based on the seven treatments which were replicated four times $\left(\begin{array}{lll}7 & \mathrm{x} & 4\end{array}\right)$. The experimental design used was Complete Randomized Design (CRD). The soil was mixed perfectly with the manure. The mixtures used are shown in Table 1.

The amended soils were watered for two weeks to stimulate the microbial decomposition of the organic manure. At the end of the two weeks two grains of Oba super 11 maize (Zea mays) were planted per pot. They were thinned down to one after germination. Mineral fertilizer was applied at the appropriate rate one week after germination to twenty pots, except in $\mathrm{T}_{2}$ (only organic manure) and $\mathrm{T}_{7}$ (control).

The pots were kept in the field moisture capacity throughout the period of experiment. The plant height and leaf area were taken on weekly basis for eight weeks using meter rule. The total dry matter yield was evaluated at the end.

\section{Field Evaluation}

The field trial was located beside the Metrological station where the soil used for the greenhouse trial was collected. The experimental design used was a Randomized Complete Block Design (RCBD). The size of the experimental field was $13 \mathrm{~m} \times 8 \mathrm{~m}$ from which fifteen plots were marked out and each plot was $3 \mathrm{~m} \mathrm{x} 1 \mathrm{~m}$. These plots were divided into three blocks and each block had five plots.

The treatments evaluated in the field on per plot basis were $\left(T_{1}, T_{2}, T_{4}, T_{5}, T_{7}\right)$. The selected treatments were based on the results of the greenhouse trial. These treatments were replicated three times. The pig manure used was incorporated into the soil and allowed to stay for two weeks to stimulate the microbial decomposition. Maize was planted two seeds per stand but later thinned to one plant per stand giving a plant population of about 53,333 plants per hectare that is at a spacing of $25 \mathrm{~cm}$ x $75 \mathrm{~cm}$. Mineral fertilizer was applied one week after germination. The field experiment was rain-fed. The plant height, number of leaves and leaf area were taken every two weeks after inorganic fertilizer application using meter rule and at maturity the yield was equally measured.

\section{Soil and Pig Dung Analyses}

Soil particle analysis was done by the Bouyoucous hydrometer method (Day, 1965) and the data fitted in the soil textural triangle to obtain the soil textural class. Organic matter was determined using Walkely-Black (1934) method, converted to soil organic matter by multiplying with a conversion factor of 1.724. Cation exchange capacity was by neutral $(\mathrm{pH} 7)$ ammonium acetate saturated method (Chapman, 1965) with the potassium and sodium in the extract determined by flame photometry (Rich, 1965) and calcium and magnesium by EDTA method (Devis and Feitas, 1970). Phosphorus was determined by the Bray 11 method (Bray and Kurtz, 1945) while total nitrogen by macro Kjeldahl method (Jackson, 1958). The $\mathrm{pH}$ was determined potentiometrically using a $\mathrm{pH}$ meter in a soil: liquid ratio of 1:2.5 the liquid being aqueous $0.1 \mathrm{~N} \mathrm{KCl}$ and distilled water (McLean, 1982) while exchangeable acidity was determined titrimetrically with $\mathrm{NaOH}$ (Mehlich, 1982).

\section{Data Analysis}

The data obtained were analyzed using analysis of variance procedure by Steel and Torrie (1980) and means were compared using Fisher's least significant difference described by Obi (2002)

\section{RESULTS AND DISCUSSION}

The results of the physicochemical properties of the soil used for the experiments (Table 2) showed that the soil was low in fertility because total $\mathrm{N}$, available phosphorous, organic carbon; exchangeable cations, cation exchange capacity (CEC) were all low in the soil. The soil is slightly acidic. The low levels of the chemical properties could be attributed to the effect of past interventions which aimed at increasing the crop yield through application of fertilizer containing only N, P and K. The analysis of the pig manure used 
gave high percentages of the required soil nutrient elements (Table 2). This indicate that apart from supplying $\mathrm{N}, \mathrm{P}$, and $\mathrm{K}$, pig manure also supplies other nutrients such as $\mathrm{Mg}$ and $\mathrm{Ca}$ in high amounts to the soil. The $\mathrm{pH}$ of pig manure was above neutral, thus it can help to neutralize the acidity and thereby provide a conducive environment for crop growth and yield.

Table 1. Different ratios of organic and inorganic manure applied in the greenhouse trial

\begin{tabular}{lllll}
\hline Treatments & N.P.K Ratio & Pig dung & Equivalent in t/ha N.P.K & Equivalent in t/ha pig manure \\
\hline $\mathrm{T}_{1}$ & $0.40 \mathrm{~g}$ & None & $0.4 \mathrm{t} / \mathrm{ha}$ & None \\
$\mathrm{T}_{2}$ & None & $10 \mathrm{~g}$ & None & $10 \mathrm{t} / \mathrm{ha}$ \\
$\mathrm{T}_{3}$ & $0.20 \mathrm{~g}$ & $5 \mathrm{~g}$ & $0.2 \mathrm{t} / \mathrm{ha}$ & $5 \mathrm{t} / \mathrm{ha}$ \\
$\mathrm{T}_{4}$ & $0.25 \mathrm{~g}$ & $2.50 \mathrm{~g}$ & $0.25 \mathrm{t} / \mathrm{ha}$ & $2.5 \mathrm{t} / \mathrm{ha}$ \\
$\mathrm{T}_{5}$ & $0.30 \mathrm{~g}$ & $1.25 \mathrm{~g}$ & $0.30 \mathrm{t} / \mathrm{ha}$ & $1.25 \mathrm{t} / \mathrm{ha}$ \\
$\mathrm{T}_{6}$ & $0.35 \mathrm{~g}$ & $0.65 \mathrm{~g}$ & $0.35 \mathrm{t} / \mathrm{ha}$ & $0.65 \mathrm{t} / \mathrm{ha}$ \\
$\mathrm{T}_{7}$ & None & None & None & None \\
\hline
\end{tabular}

Table 2. The initial physicochemical properties of soil and pig dung used in greenhouse and field study.

\begin{tabular}{|c|c|c|c|}
\hline Mechanical properties & Soil $(0-20 \mathrm{~cm})$ & Soil $(20-0 \mathrm{~cm})$ & Pig Manure \\
\hline Coarse sand $\left(\mathrm{g} \mathrm{kg}^{-1}\right)$ & 46 & 39 & - \\
\hline Fine sand $\left(\mathrm{g} \mathrm{kg}^{-1}\right)$ & 34 & 36 & - \\
\hline Clay $\left(\mathrm{g} \mathrm{kg}^{-1}\right)$ & 15 & 18 & - \\
\hline Silt $\left(\mathrm{g} \mathrm{kg}^{-1}\right)$ & 5 & 7 & - \\
\hline Textural class $\left(\mathrm{g} \mathrm{kg}^{-1}\right)$ & Sandy loam & Sandy loam & - \\
\hline \multicolumn{4}{|l|}{ Chemical properties } \\
\hline Total Nitrogen $\left(\mathrm{g} \mathrm{kg}^{-1}\right)$ & 0.098 & 0.040 & 3.22 \\
\hline Organic matter $\left(\mathrm{g} \mathrm{kg}^{-1}\right)$ & 1.32 & 0.6 & 37.96 \\
\hline Potassium $\left(\mathrm{cmolkg}^{-1}\right)$ & 0.15 & 0.1 & 0.33 \\
\hline Calcium $\left(\mathrm{cmolkg}^{-1}\right)$ & 1.5 & 0.5 & 6.6 \\
\hline Magnesium $\left(\mathrm{cmolkg}^{-1}\right)$ & 0.5 & 0.33 & 1.5 \\
\hline Sodium $\left(\mathrm{cmolkg}^{-1}\right)$ & 0.34 & 0.17 & 0.68 \\
\hline Cation exchange capacity $\left(\mathrm{cmolkg}^{-1}\right)$ & 10.88 & 0.93 & - \\
\hline Available phosphorous (ppm) $\left(\mathrm{g} \mathrm{kg}^{-1}\right)$ & 38.0 & 8.0 & 462.0 \\
\hline $\begin{array}{l}\text { Exchangeable acidity } \\
\left(\mathrm{H}+\mathrm{Al}^{3+}\right)\left(\mathrm{cmolkg}^{-1}\right)\end{array}$ & 0.6 & 0.4 & - \\
\hline pH (Soil:Water;1:2.5) & 6.4 & 4.5 & 7.9 \\
\hline pH(Soil:0.1N KCl;1:2.5) & 5.9 & 3.4 & 7.7 \\
\hline
\end{tabular}


Table 3 shows the physiochemical properties of the soil after amendment and harvesting. There were changes in both chemical and physical properties of the soil following the application of the amendments. In all the amended soils, the texture as expected remained the same (sandy loam) as it was before the application of the amendments. Total $\mathrm{N}$ decreased in all except in the one with only organic manure; possibly because of the slow release of nutrients by organic materials. The result was in line with the work done by Obigbesan (1981) where he compared organo-mineral fertilizer with mineral fertilizer that released its nutrient very fast and often got leached out before the plant could absorb them. There were decreases in organic matter in all the amended soils, an indication that the organic matter was mineralized and the maize possibly utilized the nutrients for its growth and development. This was in line with the work of Magodff (1998) where he reported that a level of organic matter higher than required to produce suitable physical properties is beneficial in that the soil has a greater buffering and nutrient holding capacity, thus improving soil productivity. There were decreases in the exchangeable $\mathrm{K}, \mathrm{Ca}$ and $\mathrm{Na}$, which showed that the plant also utilized them for growth and development. There was an increase in exchangeable $\mathrm{Mg}$ in all the amended soils except in $\mathrm{T}_{6}$ and $\mathrm{T}_{7}$ which could be as a result of low amendments added to these two treatments. The increase in exchangeable $\mathrm{Mg}$ showed that the maize plant did not need much of the $\mathrm{Mg}$ for its growth. There was a decrease in the CEC due to the decrease in the exchangeable cations. The available $\mathrm{P}$ decreased after harvesting in all the amended soils. The decrease was due to the absorption of phosphorous by plant roots for root growth, development and fixation (Bierman, 2002). The $\mathrm{pH}$ of the amended soils decreased after harvesting due to the reduction in the exchangeable cations. This could be the reason for high exchangeable acidity.

The result in Table 4 shows that the mean plant height obtained from $T_{1}$ is not statistically different from $\mathrm{T}_{2}$ while the differences between the mean plant height from $\mathrm{T}_{1}$ treatment and $\mathrm{T}_{3}$ treatment is significantly different $(\mathrm{P} \leq 0.05)$. Similarly, the differences between the mean from $T_{1}$ is significantly different from those of $\mathrm{T}_{4}, \mathrm{~T}_{5}, \mathrm{~T}_{6}$ and $\mathrm{T}_{7}$. The mean leaf area (Table 4) shows that $T_{1}$ is significant difference $(\mathrm{P} \leq 0.05)$ from those of $\mathrm{T}_{4}, \mathrm{~T}_{5}, \mathrm{~T}_{2}, \mathrm{~T}_{6}$ and $\mathrm{T}_{7}$. Finally from Table 4 the mean dry matter obtained from $\mathrm{T}_{2}$ is statistically the same $(\mathrm{P} \leq 0.05)$ with that of $\mathrm{T}_{4}$ and $\mathrm{T}_{5}$ while the differences among the mean dry matter are significantly different $(\mathrm{P} \leq 0.05)$ from those of $\mathrm{T}_{1}, \mathrm{~T}_{3}, \mathrm{~T}_{6}$ and $\mathrm{T}_{7}$. The result in Table 5 shows that the mean yield of grain obtained from $\mathrm{T}_{4}$ is not statistically different from $\mathrm{T}_{2}(\mathrm{P} \leq 0.05)$. Similarly, the mean yield of grain from $\mathrm{T}_{4}$ is significantly different $(\mathrm{P} \leq 0.05)$ from $\mathrm{T}_{1}, \mathrm{~T}_{5}$ and $\mathrm{T}_{7}$.

Table 3. The physicochemical properties of the amended soils at the end of greenhouse trial

\begin{tabular}{|c|c|c|c|c|c|c|c|}
\hline Particle sizes & $\mathrm{T}_{1}$ & $\mathrm{~T}_{2}$ & $\mathrm{~T}_{3}$ & $\mathrm{~T}_{4}$ & $\mathrm{~T}_{5}$ & $\mathrm{~T}_{6}$ & $\mathrm{~T}_{7}$ \\
\hline Coarse sand (\%) & 46 & 42 & 43 & 43 & 43 & 46 & 43 \\
\hline Fine sand $(\%)$ & 34 & 38 & 36 & 35 & 37 & 34 & 37 \\
\hline Clay $(\%)$ & 15 & 15 & 16 & 16 & 15 & 15 & 15 \\
\hline Silt (\%) & 5 & 5 & 5 & 6 & 5 & 5 & 5 \\
\hline Textural class & Sandy & Sandy & Sandy & Sandy & Sandy & Sandy & Sandy \\
\hline & loam & loam & loam & loam & loam & loam & loam \\
\hline \multicolumn{8}{|l|}{ Chemical properties } \\
\hline Total Nitrogen (\%) & 0.07 & 0.11 & 0.05 & 0.10 & 0.08 & 0.06 & 0.01 \\
\hline Organic matter $(\%)$ & 1.23 & 1.20 & 1.14 & 1.29 & 1.25 & 1.20 & 0.60 \\
\hline Exc. K (cmolkg $\left.{ }^{-1}\right)$ & 0.08 & 0.10 & 0.08 & 0.3 & 0.3 & 0.3 & 0.3 \\
\hline Exc. Ca $\left(\mathrm{cmolkg}^{-1}\right)$ & 1.2 & 1.0 & 1.2 & 0.9 & 1.2 & 1.2 & 0.4 \\
\hline Exc. $\mathrm{Mg}\left(\mathrm{cmolkg}^{-1}\right)$ & 1.0 & 0.7 & 1.0 & 1.2 & 0.6 & 0.3 & 0.2 \\
\hline Exc. $\mathrm{Na}\left(\mathrm{cmolkg}^{-1}\right)$ & 0.15 & 0.18 & 0.15 & 0.15 & 0.15 & 0.15 & 0.10 \\
\hline $\mathrm{CEC}\left(\mathrm{cmolkg}^{-1}\right)$ & 2.48 & 2.92 & 2.20 & 3.28 & 1.56 & 2.84 & 2.68 \\
\hline $\mathrm{Av} \cdot \mathrm{P}(\mathrm{ppm})$ & 16.0 & 22.0 & 24.0 & 26.0 & 19.0 & 18.0 & 8.0 \\
\hline $\begin{array}{l}\text { Exc. Acidity }\left(\mathrm{H}+\mathrm{Al}^{3+}\right) \\
(\mathrm{cmol} / \mathrm{kg})\end{array}$ & 1.2 & 1.2 & 1.2 & 1.2 & 1.2 & 0.8 & 0.8 \\
\hline $\mathrm{pH}$ (water) & 4.6 & 3.8 & 4.0 & 4.7 & 4.6 & 4.6 & 4.7 \\
\hline $\mathrm{pH}(\mathrm{KCl})$ & 3.6 & 3.6 & 3.5 & 3.8 & 3.8 & 3.6 & 3.8 \\
\hline
\end{tabular}

Legend: $\mathrm{T}_{1}=0.4 \mathrm{~g}$ NPK $15: 15: 15$ only(1:0), $\mathrm{T}_{2}=10 \mathrm{~g}$ pig dung $(0: 1), \mathrm{T}_{3}=0.20 \mathrm{~g}$ NPK and $5 \mathrm{~g}$ pig dung $(1: 25), \mathrm{T}_{4}=0.25 \mathrm{~g}$ NPK and $2.50 \mathrm{~g}$ pig dung(1:10), $\mathrm{T}_{5}=0.30 \mathrm{~g}$ NPK and $1.25 \mathrm{~g}$ pig dung(1:4), $\mathrm{T}_{6}=0.35 \mathrm{~g}$ NPK and $0.65 \mathrm{~g}$ pig dung( $(1: 3), \mathrm{T}_{7}=$ Control 
Table 4. The effect of the amendments on the agronomic properties of maize in the greenhouse trial.

\begin{tabular}{|c|c|c|c|}
\hline Treatments & Plant height $(\mathrm{cm} /$ plant $)$ & Leaf area $\left(\mathrm{cm}^{2} /\right.$ plant $)$ & Dry matter (g/plant) \\
\hline $\mathrm{T} 1$ & 111.25 & 479.50 & 9.44 \\
\hline $\mathrm{T} 2$ & 107.00 & 328.75 & 13.97 \\
\hline $\mathrm{T} 3$ & 80.50 & 303.00 & 9.43 \\
\hline $\mathrm{T} 4$ & 102.50 & 399.30 & 11.72 \\
\hline T5 & 96.00 & 369.65 & 10.68 \\
\hline T6 & 85.40 & 308.85 & 7.66 \\
\hline $\mathrm{T} 7$ & 48.10 & 141.70 & 4.85 \\
\hline F-LSD $(0.05)$ & 6.43 & 8.50 & 3.30 \\
\hline
\end{tabular}

Table 5. The effect of the amendments on the agronomic properties of maize (Zea mays) in field trial.

\begin{tabular}{|c|c|c|c|c|c|c|}
\hline Treatments & $\begin{array}{l}\text { Plant height } \\
\text { (cm/plant) } \\
\text { at 56days }\end{array}$ & $\begin{array}{l}\text { Yield of maize } \\
\text { cob }\end{array}$ & $\begin{array}{l}\text { Yield of maize grain } \\
\text { ( g/plant) }\end{array}$ & $\begin{array}{l}\text { Yield of } \\
\text { maize chaff }\end{array}$ & $\begin{array}{l}\text { Dry } \\
\text { matter }\end{array}$ & $\begin{array}{l}\text { Leaf area } \\
\text { at 56days } \\
\left(\mathrm{cm}^{2}\right)\end{array}$ \\
\hline $\mathrm{T}_{1}$ & 108.2 & 35.0 & 26.3 & 8.69 & 39.55 & 2050.0 \\
\hline $\mathrm{T}_{2}$ & 151.7 & 70.0 & 56.0 & 13.78 & 48.56 & 3325.0 \\
\hline $\mathrm{T}_{4}$ & 109.9 & 58.5 & 47.0 & 11.69 & 31.41 & 3469.0 \\
\hline $\mathrm{T}_{5}$ & 105.9 & 21.8 & 16.0 & 5.73 & 29.85 & 1806.0 \\
\hline $\mathrm{T}_{7}$ & 74.3 & 16.1 & 11.0 & 5.06 & 20.45 & 1500.0 \\
\hline F- & 31.59 & 23.68 & 20.18 & 3.75 & 4.32 & 670.4 \\
\hline
\end{tabular}

$\operatorname{LSD}_{(\mathrm{p}=0.05)}$

Legend: $\mathrm{T}_{1}=0.4 \mathrm{~g}$ NPK 15:15:15 only (1:0), $\mathrm{T}_{2}=10 \mathrm{~g}$ pig dung $(0: 1), \mathrm{T}_{4}=0.25 \mathrm{~g}$ NPK and $2.50 \mathrm{~g}$ pig dung $(1: 10)$, $\mathrm{T}_{5}=0.30 \mathrm{~g}$ NPK and $1.25 \mathrm{~g}$ pig dung $(1: 4), \mathrm{T}_{7}=$ Control

This increase could be possible because of more availability of nutrients and their uptake which increased plant height, leaf area and weight of dry matter, cob, grain, chaff. Similar findings were also reported by Tiwari and Parihar (1992), Ramesh et al., (1999), Gorttappeh et al., (2002), Saeed et al., (2002), who stated that organic manure alone or in combination with synthetic fertilizers significantly increased agricultural yield and biological yield of crops against control. This stem from the fact that both could be used to increase the nutrient status of the soil and/or reduce the acidity of the soil thereby making exchangeable cations available to plants.

Comparatively $\mathrm{T}_{4}$ had higher significant effect $(\mathrm{P} \leq 0.05)$ than $\mathrm{T}_{5}$ in the yield components of maize namely cob, grain and chaff. Thus $\mathrm{T}_{4}(0.25 \mathrm{t} / \mathrm{ha}$ N.P.K $+2.5 \mathrm{t} / \mathrm{ha}$ pig dung) was recommended. This also had positive significant effects on the physicochemical properties.

\section{CONCLUSION AND RECOMMENDATION}

The study showed that the yield and the yield components of maize were enhanced by the application of a combination of pig dung and NPK fertilizer mixture although there was significant response on pig dung. The application of organic and inorganic fertilizers improved the physicochemical properties of the soil when compared to the control.
Thus, the use of pig dung manure or in combination with NPK inorganic fertilizer in maize production especially in an ultisol (sandy loam) is recommended rather than the use of only NPK mixture.

\section{REFERENCES}

Bierman, R. (2002). The effect of organic and inorganic fertilizer on Temperate soil. Bioresource Technology 44: 249-252.

Carlson, C. N., Grunes, D.L., Allesi, J. and Reichman, G.A.(1961). Corn growth on garden surface and subsoil as affected by application of fertilizer and manure. Soil Sci.Soc. Amer.Proc, 25, 44-7.

Chapman, H.D. (1965). Cation Exchange Capacity In Method of Soil Analysis Part II, Agronomy No.9, Black, C.A. (ed) Am.Soc. of Agronomy Medison, Wisoconsin pp. 891-901.

Davis, J. and F. Freitas (1970). Physical and chemical methods of Soil and Water analysis. Soil Bulletin No. 10. FAO, Rome.

Gorttappeh, A.H., Ghalavand A., Ahmady M.R.and Mirnia S.K. (2000). Effect of organic, inorganic and integrated fertilizers on quantitative and qualitative traits of different cultivars of sunflower (Helianthus annuus L.) in western Azarbayjan. Iran J.Agric.Sci. 6(2): 85-104. 
Jacinthe, P. A. I.; Lal, R.I; Kimbel J. M. S. (2002). Effect of wheat residue fertilization on accumulation and biochemical attributes of organic carbon in a central Ohio luvisol. Soil Sci 167 (11). 750-758.

Jackson, M.L. (1958). Total Nitrogen determination (Modified Kjheldahl method) Soil Chemical Analysis Prentice - Hall, Englewood cliff, New Jersey, pp.498.

Magodff, F. (1998). Building soils for Better crops. Organic matter Management. North East Region Sustainable Agricultural Research Program.

McLean, E.O. (1982). Soil pH and lime requirements. In: Methods of Soil Analyses Part II, Page, .L.,R.A. Miller, D.R. Keeney (eds). Chemical and Microbial Properties. American Society of Agron. Medison Wiscosin, U.S.A. pp 199-220.

Mehlich, A. (1976). New buffer method for rapid estimation of exchangeable acidity and lime requirement. Commun Soil Sci Plant Anal. 7(7):637-52.

Obi, I.U., (2002). Statistical methods of detecting differences between treatment means and research methodology issues in laboratory and field experiments. Second edition. AP Express publisher Limited. Nsukka -Nigeria. In Agronomy abstracts. 1994 ASA.

Obigbesan, G. O. (1981). Nutrient requirements of yams (Dioscorea species). Agricultural Research Bulletin Vol. 2 No. 1, Faculty of Agric. Univ. of Ibadan, pp.48.

Olayinka, A. and Adebayo, A. (1985). The effect of methods of application of sawdust on plant growth, plant growth, plant nutrients uptake and soil chemical properties. Plant and Soil 86 (1) 47- 56.
Omaliko, C. P. E., and Agbim, N.N. (1983). Forage corn response to rice - mill wastes and fertilizer. J. Environ. Qual. 12: $320-324$.

Ramesh,S., Raghbir S. and Mohinder S.(1999). Effect of phosphorus, Iron and FYM on yield and quality of sunflower. Annals Agri. Biol. Res., 4(2): 145-150.

Rich, C.L. (1965). Elemental Analysis by flame photometry In Method of Soil analysis. America Soc Of Agron. C.A. Black (ed). No. 9 pp.849-860.

Saeed, N., Hussain M. and Saleem M. (2002). Interactive effect of biological sources and organicamendedments on the growth and yield attributes of sunflower (Helianthus annuus L.). Pak. J.Agric. Sci., 39(2): 135-136.

Steel,R.G.D. and Torrie,J.H.(1980).Principle and procedures of statistics $\left(2^{\text {nd }} E d\right.$ )Megrew-Hill Book Company Inc. N.Y.P. 633.

Stewart, B. A., Porter L. K. and Viets,F.G. (1966). Effect of sulphur content of straws rates of decomposition and plant growth. Soil Sci. Soc. Amer. Proc. 30: $355-358$.

Tiwari, R.B. and Parihar S.S. (1992). Effect of nitrogen and variety on grain yield and net profit of lower. Advances in Plant Sciences, 5(1): 173-175.

Uzo, J. O. and Asiegbu J.E. (1982). Yield components responses of vegetable crops to farmyard manure rates in the presence of inorganic fertilizers Hortic. Res. Vol. 3:243-252.

Walkley, A. and Black, I. A. (1934). An examination of the Degtjareff method for determining soil organic matter and a proposed modification of the chromic acid titration method. Soil Sci. Amer. 37: 29 -38. 